\title{
Caracterización funcional a base de harina de desayuno de cereal Oxalis tuberosa agregar fibra
}

\section{Characterization Functional a Cereal Breakfast Based Flour Oxalis tuberosa Add Fiber}

\author{
Marisol Patricia Castro Mendoza ${ }^{a}$, Erick Heredia Olea ${ }^{b}$, Heidi María Palma Rodríguez a , Apolonio Vargas \\ Torres $^{a}$, Juan Pablo Hernández Uribe ${ }^{a}$
}

\begin{abstract}
:
Breakfast cereals have health benefits in combination with a balanced diet; They play an important role in the diet since they ensure the proper functioning of the organism, the nervous system and the gastrointestinal tract. One of the most used technologies currently in the preparation of breakfast cereals, is extrusion. Therefore, the objective of this study was to obtain an extruded cereal high in fiber, based on tuberous Oxalis flour and oat fiber, with acceptable physicochemical properties (expansion index, bulk density, absorption and solubility in water). Five treatments were obtained by means of extrusion. The highest value of expansion index was obtained by treatment 5 (13\% humidity-100\% Oxalis tuberosa flour). The apparent density results were in a range of $0.13-0.51 \mathrm{~g} / \mathrm{ml}$, treatment 4 and treatment 2 , respectively. The results for water absorption index were in a range between 2.8-4.2 g H20 / g sample, obtaining the lowest value for treatment 4 . The water solubility index results showed that the highest value was obtained for the water solubility index. treatment 5 and the lowest for T1 and $\mathrm{T} 2$.
\end{abstract}

\section{Keywords:}

Breakfast cereal, Oxalis tuberosa, oat fiber, extrusion, expansion index, bulk density

\section{Resumen:}

Los cereales para desayuno presentan beneficios a la salud en combinación con una dieta equilibrada; juegan un papel importante en la dieta ya que aseguran el funcionamiento adecuado del organismo, el sistema nervioso y el tracto gastrointestinal. Una de las tecnologías más utilizadas actualmente en la elaboración de cereales para desayuno, es la extrusión. Por lo tanto, el objetivo de este estudió fue obtener un cereal extrudido alto en fibra, a base de harina de Oxalis tuberosa y fibra de avena, con propiedades fisicoquímicas aceptables (índice de expansión, densidad aparente, absorción y solubilidad en agua). Se obtuvieron 5 tratamientos por medio de extrusión. El valor más alto de índice de expansión lo obtuvo el tratamiento 5 (13\% de humedad-100\% harina de Oxalis tuberosa). Los resultados de densidad aparente estuvieron en un intervalo de 0.13-0.51 g/ml, tratamiento 4 y tratamiento 2, respectivamente. Los resultados para índice de absorción de agua estuvieron en un rango entre 2.8-4.2 g H20/g muestra, obteniendo el valor más bajo para el tratamiento 4. Los resultados de índice de solubilidad de agua mostraron que el valor más alto fue obtenido para el tratamiento 5 y el más bajo para la T1 y $\mathrm{T} 2$.

Palabras Clave:

Cereal para desayuno, Oxalis tuberosa, fibra de avena, extrusión, índice de expansión, densidad aparente

\footnotetext{
a Autor de Correspondencia, Universidad Autónoma del Estado de Hidalgo, Instituto de Ciencias Agropecuarias, Email: marisol1789@hotmail.com ${ }^{\text {a }}$ erickho@itesm.mx ${ }^{\text {b }}$ palma.heidi@gmail.com ${ }^{\text {a }}$ apolovt@hotmail.com ${ }^{\text {a }} \underline{\text { heurjupa@gmail.com }}^{\text {a }}$

a Universidad Autónoma del Estado de Hidalgo, Instituto de Ciencias Agropecuarias (ICAP), Av. Universidad km 1, Rancho Universitario, C.P. 43600, Tulancingo de Bravo, Hidalgo, MÉXICO.

b Instituto Tecnológico de Estudios Superiores de Monterrey Escuela de Ingeniería y Ciencias (EIC), Av. Eugenio Garza Sada 2501 Sur, C.P. 64849, Monterrey, Nuevo León, MÉXICO.
} 


\section{Introducción}

Currently, as a change in lifestyle, there has been an increase in the demand for processed foods, however, the consumer is more concerned with the relationship between food and health. Breakfast cereals play an important role in the diet because they ensure the proper functioning of the organism, the nervous system and the gastrointestinal tract. The consumption of a breakfast has been associated with a higher intake of fiber and calcium, as well as a lower risk of overweight or obesity (Spence, 2017). Extrusion cooking is a versatile, low cost and very efficient technology in food processing (Escalante-Aburto, et al., 2014), this technology is widely used by the food industries in the production of breakfast cereals, food for babies, snacks, meat analogs and modified starches (Ding, et al., 2005). There is the possibility of manipulating the nutritional value of extruded products by incorporating raw materials rich in bioactive components (such as carotenoids, dietary fiber, etc.). There are new botanical sources, which are sought to be exploited for their high content of bioactive compounds which give great benefits to health; One of these new sources is Oxalis tuberosa, which is a source of little known and exploited resources that represent possibilities for agriculture, food. Oxalis tuberosa represents a good source of antioxidants, so it can be considered as an excellent raw material option for the elaboration of foods with functional properties. The objective of this work is the preparation of a cereal for breakfast using Oxalis tuberosa as raw material, which is rich in bioactive compounds, since at present there are no breakfast cereals based on tubers.

MATERIALS AND METHODS. The Oxalis tuberosa was acquired in the local market of Acaxochitlán, Hidalgo. The oat fiber (Vitacel $®$ HF401) was donated by the laboratory J. RETTENMAIER USA LP. For the preparation of breakfast cereal, 5 formulations were made according to Table 1, where the moisture, fiber and flour content of Oxalis tuberosa varied. For the preparation of breakfast cereal, a Bühler double screw extruder was used at a temperature of 145-155 ${ }^{\circ}$ $\mathrm{C}$ and a screw speed of $250 \mathrm{rpm}$.

Cuadro 1. Formulación (\%) de los distintos tratamientos obtenidos por extrusión

\begin{tabular}{|c|c|c|c|}
\hline Tratamientos & Fibra de avena & Harina de Oxalis tuberosa & Humedad \\
\hline 1 & 20 & 80 & 20 \\
\hline 2 & 0 & 100 & 20 \\
\hline 3 & 10 & 90 & 17.5 \\
\hline 4 & 20 & 80 & 13 \\
\hline 5 & 0 & 100 & 13 \\
\hline
\end{tabular}

Expansion Index (EI). The Expansion Index was determined according to the method reported by Escalante-Aburto, et al., (2014). It was used the following formula: El=Sample diameter/diameter of the extruder die.

Bulk density (BD). The Bulk Density (BD) was determined following the methodology reported by Lo, et al., (1998). The determinations were made at 5 extruded per treatment. The density of the sample was calculated in $\mathrm{g} / \mathrm{cm} 3$.

Water solubility index (WSI) and water absorption index (WAI). The solubility index and water absorption index was determined according to the procedures described by Anderson, et al., (1970) with some modifications. The determinations were made in triplicate. The WAI were analyzed using the following formula: 


$$
W A I=\left(\frac{\text { weight of wet sediment }}{\text { weight of dry sample }}\right) \times 100
$$

And the WSI using the following formula:

$$
W S I=\left(\frac{\text { weight of dissolved solids in supernatant }}{\text { weight of dry sample solids in the original sample }}\right) \times 100
$$

Scanning Electron Microscopy (SEM). The scanning electron microscopy analyzes were performed on the extruded samples according to the procedure of Zazueta-Morales, et al., (2002). The samples were placed on a double adhesion copper conductive tape, which was previously fixed on an aluminum support of the scanning electron microscope JEOL JSM-5800LV. The sample was covered with a $30 \mathrm{~nm}$ carbon layer and then placed in the JEOL metal ionizer and coated with a gold layer.

Experimental design and statistical analysis. For the breakfast cereal, a two-factor design was used, \% moisture and\% oat fiber, with three levels each. A composite, rotable, central experimental design with a value of $\alpha=1.682$ was used. An analysis of variance (ANOVA) was performed with a level of significance of $95 \%(\alpha=0.05)$. For the comparison of means, the method of multiple comparisons will be used by the Tukey test at the same level of significance. To obtain the results, the statistical program Sigma-Stat (SYSTAT software, 2010) will be used.

\section{RESULTS AND DISCUSSION}

The index of expansion of the extrudates varied from 1.32-2.56 (Table 1). The highest index of expansion was obtained with treatment 5 , on the contrary, the lowest value was for treatment 1 . The moisture content contributes to the formation of bubbles together with the action of temperature, and in this way the sample expands. When the starch is gelatinized during extrusion, a matrix is formed that traps water vapor and allows the formation of bubbles (Guy, et al., 1988). Ding, et al., (2005), found that humidity is the main factor that affects the density of extrudates and their expansion.

Tabla 1. Results of expansion index, bulk density, water solubility index and water absorption index of the different formulations

\begin{tabular}{ccccc}
\hline Treatments & EI & BD & WSI & WAI \\
\hline Treatment 1 & $1.32 \pm 0.22^{\mathrm{a}}$ & $0.41 \pm 0.015^{\mathrm{a}}$ & $33.4 \pm 2.5^{\mathrm{a}}$ & $3.8 \pm 0.23^{\mathrm{ab}}$ \\
\hline Treatment 2 & $1.60 \pm 0.39^{\mathrm{b}}$ & $0.51 \pm 0.014^{\mathrm{b}}$ & $32.3 \pm 2.5^{\mathrm{a}}$ & $4.0 \pm 0.44^{\mathrm{b}}$ \\
\hline Treatment 3 & $1.65 \pm 0.42^{\mathrm{b}}$ & $0.22 \pm 0.002^{\mathrm{c}}$ & $39.1 \pm 4.7^{\mathrm{a}}$ & $4.2 \pm 0.51^{\mathrm{b}}$ \\
\hline Treatment 4 & $1.73 \pm 0.85^{\mathrm{c}}$ & $0.13 \pm 0.0005^{\mathrm{d}}$ & $44.5 \pm 7.1^{\mathrm{b}}$ & $2.8 \pm 0.15^{\mathrm{a}}$ \\
\hline Treatment 5 & $2.56 \pm 0.51^{\mathrm{d}}$ & $0.14 \pm 0.0008^{\mathrm{d}}$ & $49.1 \pm 1.4^{\mathrm{b}}$ & $3.7 \pm 0.14^{\mathrm{ab}}$
\end{tabular}

Expansion Index. BD: Bulk Density. WSI: Water Solubility Index. WAI: Water Absortion Index

Average of 3 repetitions \pm standard deviation. Equal letters indicate that there are no significant differences, different letters if there are significant differences. 
The apparent density results of the different treatments were in a range of $0.13-0.51 \mathrm{~g} / \mathrm{cm} 3$ (Table 1), the lowest value was for the extruded ones corresponding to treatment 5 and the highest value for treatment 2 . These results were equal that in the previous parameter, they show the same behavior, since when increasing the moisture content the elasticity of the mass is reduced through the plasticization of the melt, which results in a reduction of the gelatinization, decreasing the expansion and increasing the bulk density of the extrudate (Mercier and Feillet 1975). Similar results reported in the present work were those obtained by Singh, et al. (2013) who developed extruded snacks based on a mixture of potatoes, rice and chickpeas, the authors reported that possibly the increase of moisture content during extrusion can reduce the elasticity of the dough through the plasticization of the starch, which reduces the specific mechanical energy and, therefore, reduces the gelatinization, decreasing the expansion and increasing the bulk density of the extrudate. The hydration properties were analyzed, by Solubility Index and Water Absorption Index. These two parameters are indicators of the level of damage occurred in the starch of the food during extrusion processing (Hernández-Díaz et al., 2007). The solubility index in water can be used as an indicator of the degradation of macromolecules (proteins and carbohydrates), by measuring the amount of soluble elements of the starch after extrusion (Ding, et al., 2005). The values obtained for ISA were found in a range of 32.3-49.1\%. The highest values were for treatment 5 and lower for treatment 2. Camacho-Hernández, et al., (2014), observed that when increasing the moisture content the ISA decreased significantly, this in expanded corn-based snacks blue and corn starch. This may be due to the fact that an increase in feed moisture reduces the friction of the mass in the extruder, so that the fragmentation of the material is limited. In addition, the lubricating effect supplied by the water causes the sample to pass faster through the extruder. The water absorption index (IAA) measures the amount of water absorbed by the starch and can be used as an index of starch gelatinization during the extrusion process (Anderson, et al., 1969). The water absorption index values were between $2.8-4.2 \mathrm{gH}_{2} \mathrm{O} / \mathrm{g}$ (Table 1); the lowest value was for $\mathrm{T} 4$ and the highest for treatment 3. This behavior may be due to the higher proportion of potato flour in the different formulations Allen, et al., (2007), noted that amylopectin has greater capacity of water absorption with respect to amylose, in such a way that starches with a high content of this biopolymer have a higher IAA, as can be seen in Table 1, the formulations with the highest content of Oxalis tuberosa flour resulted in a greater water absorption. The structural characterization was done by means of Scanning Electron Microscopy (SEM). The micrographs taken to the different treatments obtained by extrusion are shown in Fig. 1. As can be seen the number and size of pores formed during the extrusion process differs between each of the formulations and is directly related to the results of the index of expansion. A larger number and size of the pores results in a high expansion rate. The highest value of expansion index was obtained for treatment 5 , when observing the micrograph corresponding to this treatment, larger pores are distinguished and in a more defined way. On the contrary, treatments with a lower expansion index exhibit pores of smaller size and heterogeneous shape. Bisharat, et al., (2013).

CONCLUSION. Applying the extrusion technology it was possible to obtain a breakfast cereal based on Oxalis tuberosa flour, with aceptable Physicochemical characteristics. However, moisture content was the main factor that significantly affected the extruded evaluations. The decrease in moisture content (13\%) increased the values of IE and ISA, while DA decreased.

\section{BIBLIOGRAPHY}

Anderson R., Conway H., Peplinski A. (1970). Gelatinization of Corn Grits by Roll Cooking, Extrusion Cooking and Steaming. Starch/Starkë, 4, 130-135.

Bisharata G., Oikonomopoulou V., Panagiotou N., Krokida M.., Maroulis Z. (2013) Effect of extrusion conditions on the structural properties of corn extrudates enriched with dehydrated vegetables. Food Research International, 53, 1-14. 
Camacho-Hernández I., Zazueta-Morales J.J, Gallegos-Infante J.A., Aguilar E., Rocha-Guzmán N.E., Navarro-Cortez R., Jacobo-Valenzuela N.,. Gómez-Aldapa C.A. (2014). Effect of extrusion conditions on physicochemical characteristics and anthocyanin content of blue corn third-generation snacks, CyTA - Journal of Food, 12, 4, 320-330.

Ding Q., Ainsworth P., Tucker G., Marson H. (2005) The effect of extrusion conditions on the physicochemical properties and sensory characteristics of rice-based expanded snacks, Journal of Food Engineering, 66, 283-289.

Escalante-Aburto A., Ramírez B., Torres P., López J., Figueroa J., Barrón J., Morales I., Ponce N., Gutiérrez R. (2014). Obtaining Ready-to-Eat Blue Corn Expanded Snacks with Anthocyanins Using an Extrusion Process and Response Surface Methodology, Molecules, 19, 21066-21084.

Guy y Horne. (1988). Extrusion and co-extrusion of cereals, Food Structure - Its creation and evaluation, 331-339.

Hernández-Díaz J, Quintero-Ramos A., Barnard R., Balandrán-Quintana R. (2007) Functional Properties of Extrudates Prepared with Blends of Wheat Flour/Pinto Bean Meal with Added Wheat Bran, Food science technology international, 13, 301-308.

Lo T., Moreira R., Castell M. (1998). Effect of operating conditions on melt rheological characteristics during twin-screw food extrusion. Transactions of the ASAE, 41, 1721-1728.

Mercier C., Feillet P. (1975). Modification of Carbohydrate Components by Extrusion-Cooking of Cereal Products, Cereal chemistry, 52, 283-97.

Spence C. (2017). Breakfast: The most important meal of the day? International Journal of Gastronomy and Food Science, 8, 1-6.

Thymi S., Krokida M., Pappa A., Maroulis Z. (2004). Structural properties of extruded corn starch, Journal of food engineering, 68, 519-526. 